\title{
Familial hypouricaemia associated with renal tubular uricosuria and uric acid calculi: case report
}

\author{
JM HEDLEY AND PJ PHILLIPS \\ From the Royal Adelaide Hospital, Adelaide, and the Division of Clinical Chemistry, Institute of \\ Medical and Veterinary Science, Adelaide, South Australia 5000
}

SUMMARY We describe a patient with the rare combination of uric acid calculi, familial hypouricaemia, and increased renal urate clearance.

\section{Case report}

A 63-year-old man was admitted to the Royal Adelaide Hospital with a two-week history of suprapubic discomfort, urinary frequency, and haematuria. He had a past history of a partial gastrectomy 11 years previously for a leiomyoma of the stomach, a stroke eight years previously, when hypertension was discovered, and of a renal uric acid calculus 18 months previously. He had been treated with amitriptyline and guanethidine for eight years and phenylbutazone and sulphamethizole for two weeks.

Examination was normal except for a left hemiparesis. Routine investigations showed persistent hypouricaemia with plasma urate concentraticns less than $0.08 \mathrm{mmol} / 1(1.3 \mathrm{mg} / \mathrm{dl})$ on many occasions $(95 \%$ reference range in healthy male laboratory staff $0 \cdot 25-0.45 \mathrm{mmol} / 1 ; 4 \cdot 2-7 \cdot 6 \mathrm{mg} / \mathrm{dl}$ ). There was no other abnormality in the multiple biochemical analysis (Sequential Multiple Analyser with Computer, Technicon, Tarrytown, USA). Hypouricaemia had also been present eight years and one year earlier $(0.09 \mathrm{mmol} / \mathrm{l}(1.5 \mathrm{mg} / \mathrm{dl})$ and $0.06 \mathrm{mmol} / 1$ $(1.0 \mathrm{mg} / \mathrm{dl}))$. On neither occasion had he been taking drugs known to affect the determination of plasma urate. ${ }^{1}$ Urinary urate excretion 10 days after stopping his drugs and on a ward diet was 4.6 and $6.2 \mathrm{mmol} / \mathrm{d}$ ( 773 and $1042 \mathrm{mg} / \mathrm{d}$ ) (reference range 2.4-7.0 $\mathrm{mmol} / \mathrm{d}:(403-1176 \mathrm{mg} / \mathrm{d}))$ and urate to creatinine clearance ratio was 1.33 and 1.69 (normal $0.097-0 \cdot 11)^{2}$ There was no excess of xanthine, amino acids, or glucose in his urine, and rheumatoid and antinuclear factor were not detected in serum. Urinary Bence Jones protein and blood salicylates were not detected, and the serum electrophoretic pattern, ESR ( $6 \mathrm{~mm} / \mathrm{hour})$, and serum copper and

Received for publication 10 March 1980 lead concentrations were normal. At cystoscopy a $3 \mathrm{~cm}$ bladder calculus was found, and analysis showed it to be composed entirely of uric acid.

Investigation of family members showed his two surviving brothers to be hypouricaemic $(0.06$ and $0.08 \mathrm{mmol} / \mathrm{l}(1.0$ and $1.3 \mathrm{mg} / \mathrm{dl}))$ and his sister to have a low normal plasma urate concentration $(0.19 \mathrm{mmol} / 1(3.2 \mathrm{mg} / \mathrm{dl}), 95 \%$ reference range in women $0 \cdot 15-0.40 \mathrm{mmol} / \mathrm{l}(2 \cdot 5-6 \cdot 7 \mathrm{mg} / \mathrm{dl}))$. The patient's three adult daughters were hypouricaemic $(0 \cdot 12,0 \cdot 13$, and $0 \cdot 14 \mathrm{mmol} / \mathrm{l}(2 \cdot 0,2 \cdot 2$, and $2 \cdot 4 \mathrm{mg} / \mathrm{dl}))$. There was no family history of renal stones.

The patient and other members of the family refused further investigations but at the time of this report remain well.

\section{Discussion}

Hypouricaemia may be caused by decreased production or increased excretion of uric acid. Decreased urate production occurs classically with abnormalities of xanthine oxidase, which may be genetic (as in xanthinuria) or acquired (as with allopurinol) but may also partly explain the hypouricaemia seen in patients with liver disease and malnutrition or receiving parenteral nutrition with glucose solutions.

Increased plasma urate clearance could theoretically occur by renal or gastrointestinal routes, but only increased renal urate clearance has been described. Classically, it occurs in combination with generalised disorders of renal tubular transport (Fanconi syndrome), but isolated increase in renal urate clearance occurs in pregnancy, with salt loading, ${ }^{3}$ in patients with neoplasia, and with a variety of drugs. ${ }^{1}$ There are only a few reports of isolated, apparently primary, hypouricaemia with increased renal urate clearance..$^{4-10}$ Of these, only four are suggestive of a hereditary syndrome, ${ }^{5-8}$ and only one patient presented with a uric acid calculus. ${ }^{10}$ 
Hypouricaemia of renal origin can be caused by decreased tubular reabsorption and/or increased secretion. Our patient resembles those in whom the urate clearance exceeds the estimated glomerular filtration rate. 69 This implies increased renal tubular secretion although we cannot exclude impaired tubular reabsorption as well.

In our patient urate production was normal, and there was no evidence of an exogenous cause for increased renal urate clearance or other renal tubular dysfunction. We postulate that he had a hereditary isolated renal tubular disorder. The inheritance was probably as an autosomal dominant since relatives of both sexes were affected and there were no known consanguineous marriages. The other case report of hypouricaemia with uric acid stones also had a greatly increased urate clearance. ${ }^{10}$ In such patients the rate of excretion of a urate load would be increased, and intermittent increased urinary urate concentrations would predispose to renal uric acid stones.

We thank Dr D Kennedy and Mr M Hamilton, of the Royal Adelaide Hospital, for permission to report this patient who was under their care, and Professor BT Emmerson, of the University of Queensland, for advice.

\section{References}

${ }^{1}$ Kelley WN. Hypouricaemia. Arthr Rheum 1975;18
(Suppl):731-7.

2 Afzal Mir M, Delamore IW. Hypouricaemia and proximal tubular dysfunction in acute myeloid leukaemia. $\mathrm{Br}$ Med J 1974;3:775-7.

${ }^{3}$ Holmes EW, Kelley WN, Wyngaarden JB. The kidney and uric acid excretion in man. Kidney Int 1972;2:115-8.

4 Praetorius E, Kirk JE. Hypouricaemia: with evidence for tubular elimination of uric acid. J Lab Clin Med 1950; 38:865-8.

${ }^{5}$ Greene ML, Marcus R, Aurbach GD, Kazam ES, Seegmiller JE. Hypouricaemia due to isolated renal tubular defect. Dalmation dog mutation in man. Am J Med 1972;53:361-7.

- Khachadurian AK, Arslanian MJ. Hypouricaemia due to renal uricosuria. Ann Int Med 1973;78:547-50.

7 Akaoka I, Nishizawa T, Yano E et al. Familial hypouricaemia due to renal tubular defect of urate transport. Ann Clin Res 1975;7:318-24.

${ }^{8}$ Sperling $\mathbf{O}$, Weinberger A, Oliver I, Liberman UA, de Vries A. Hypouricaemia, hypercalciuria and decreased bone density. A new hereditary syndrome. Ann Int Med $1974 ; 80: 482-7$.

- Simkin PA, Skeigh MD, Healey LA. Suppression of uric acid secretion in a patient with renal hypouricaemia. Isr J Med Sci 1973;9:1113-6.

${ }^{10}$ Kawabe K, Murayama T, Akaoka I. A case of uric acid renal stone with hypouricaemia caused by tubular reabsorptive defect of uric acid. J Urol 1976;116:690-2.

Requests for reprints to: Dr JM Hedley, Royal Flying Doctor Service, 4 Vincent Street, Port Augusta, South Australia 5700. 